\title{
Cara e cruz: conflito político, territorio e padroado rexio en Galicia durante o reinado de Afonso $X$ e Violante de Aragón*
}

\author{
Rosa M. Rodríguez Porto \\ Universidade de Santiago de Compostela
}

DOI: $10.17075 /$ gtax.2021.006 
* Parte das ideas presentadas neste traballo foron formuladas orixinalmente en Historia e culto das raínas santas da Casa de Hungría nos reinos occidentais da Península (Ss. XIII e XIV). Memoria inédita da Bolsa de Investigación da Deputación da Coruña (2011). Agradézolle a Ricardo Pichel a súa xenerosa axuda, comentarios e suxestións. 


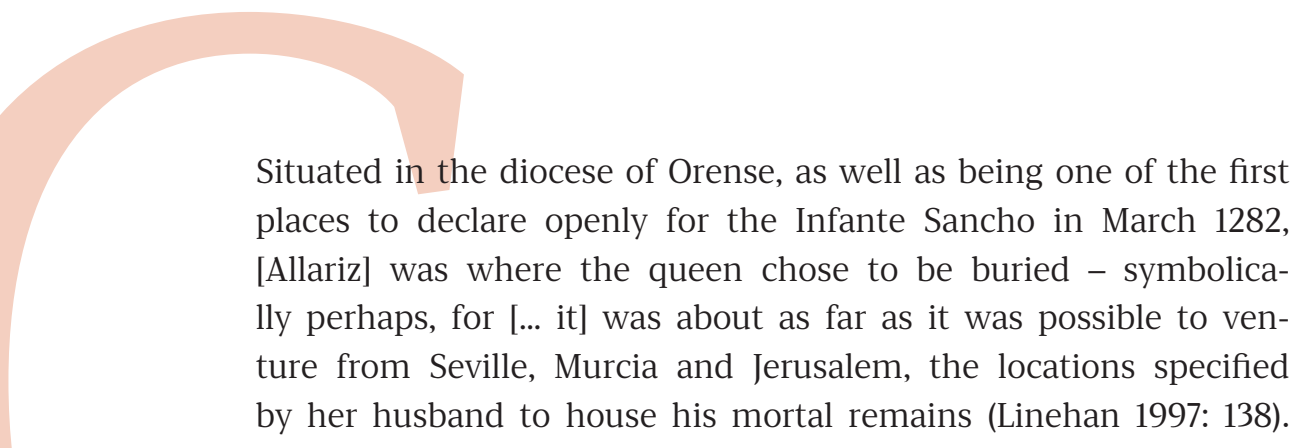

Coa súa ironía habitual, Peter Linehan referíase así á decisión da raíña Violante de ser soterrada no convento de Santa Clara de Allariz, que ela mesma fundara no ano en que o infante Sancho se rebelou contra seu pai, facendo voar os vimbios que mantiñan unida a familia real e o propio reino dende a morte do herdeiro Fernando de la Cerda. Como ben sinalaba o historiador británico, rei e raíña non podían terse afastado máis na altura da súa morte, facendo patente na súa distancia no só a ruptura conxugal mais tamén a diferenza entre as súas posturas ante un presente incerto. Porén, as diverxentes actitudes de Afonso e Violante cara a Galicia poderían revelar ademais unha concepción distinta do papel que este territorio habería de xogar no taboleiro político ibérico a finais do século XIII, máis importante do que o seu suposto carácter periférico permitiría adiviñar. Neste senso, un exame pausado do rexistro documental e do intricado relato histórico destas décadas convulsas permitirá recoñecer trazas destas visións irreconciliables xa con anterioridade, contextualizar mellor a fundación allaricense, así como outros xestos de favor que a raíña mostrou cara ao antigo reino galego, ademais dos intentos da nobreza e da Igrexa locais por suscitar o apoio da soberana fronte á indiferenza -se non aberta hostilidade- do Rei Sabio.

\section{AFONSO X E O CABIDO COMPOSTELÁN: CRÓNICA VISUAL DUN DESACORDO}

Unha das imaxes máis coñecidas do Rei Sabio é a que se encontra no Tombo A compostelán (Arquivo da Catedral de Santiago, CF 34, fol. 71r; Fig. 1), reproducida en infinidade de ocasións en toda clase de obras e materiais relativos ao seu reinado. Aparece alí efixiado a cabalo e armado coa lanza, unha representación que ten a súa inspiración -de igual modo que as dos reis de León, Fernando II (fol. 44v) e Afonso IX (fol. 62v)- na sixilografía, como sinalou Rocío Sánchez Ameijeiras (2008: 213). De facto, é moi probable que o modelo inmediato desta ilustración fose o selo pendente 


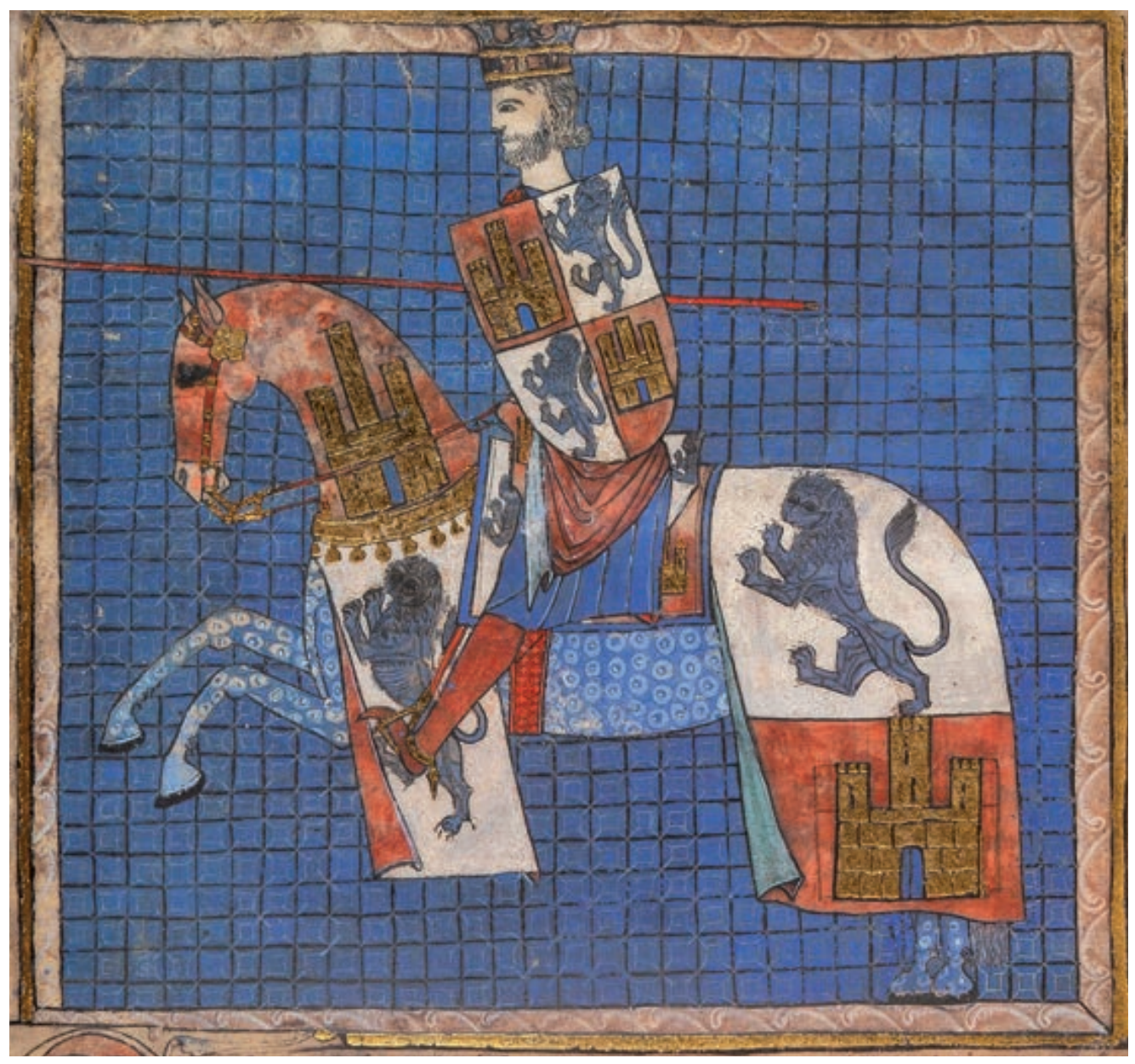

Fig. 1: Afonso X. Tumbo A (Arquivo da Catedral de Santiago de Compostela, CF 34, fol. 71r).

do documento orixinal copiado xusto a continuación da imaxe, o único correspondente a Afonso X en todo o códice. Trátase dun privilexio polo cal o Rei Sabio outorga ao arcebispo Xoán Arias († 1266) e aos seus sucesores a vila e alfoz de Xallas, datado o 4 de novembro de 1255 en Burgos ${ }^{1}$. A pesar das obvias limitacións do miniaturista, o uso de ouro e a multiplicación dos cuarteis de Castela e León no escudo e na montura confiren certa solemnidade á imaxe. Aínda así, as efixies do rei e de seu pai Fernando III non poden compararse coas que ornaban os folios precedentes desta colección documental, testemuñando que os tempos de gloria de Compostela xa pasaran, tras a unificación dos reinos e o subseguinte desprazamento da basílica xacobea como centro cerimonial e panteón rexio. Non obstante, é probable que o ambicioso prelado compostelán pensase que non todo estaba perdido e que pagaba a pena actualizar a

1 Véxase o doc. 75 do diplomatario recompilado por Francisco Javier Pérez neste volume. 
galería rexia do Tombo A coa incorporación do Rei Sabio e seu pai, co fin de suscitar no novo soberano o desexo de emular aos seus predecesores.

Aínda que é preciso encadrar esta intervención en datas moi próximas á da emisión do documento orixinal, quizais contra 1256, xa antes -na altura de 1238, momento do seu ascenso á dignidade arcebispal- Xoán Arias decidira engadir ao códice toda unha serie de confirmacións e concesións de Fernando III á sé (fols. 67r-69v). Este feito dá unha idea do carácter inaugural e programático da empresa, acorde coa súa vontade de devolver á catedral compostelá a preeminencia de época xelmiriana. A esta iniciativa seguirían outras, que mostran as inquedanzas e recursos do que Linehan (1971: 265) consideraba «one of the greatest ecclesiastical pirates of thirteenth-century Spain»: a construción dun gran pazo arcebispal -mal chamado «de Xelmírez»- e un claustro que servirá de modelo ás outras catedrais galegas, incluíndo a fundación dunha Capela dos Arcebispos destinada ao enterramento dos prelados de Santiago, así como o frustrado proxecto de renovación da cabeceira catedralicia consonte o novo gusto gótico, seguindo o exemplo da sé leonesa². Que a primeira ampliación do Tombo A só fose decorada con iniciais iluminadas mentres que para a segunda se decidise engadir dúas ilustracións, ocupando cada unha máis de medio folio, deixa ver que o arcebispo tiña postas grandes esperanzas no novo monarca. A este respecto, o coidado en acomodar as efixies de Fernando III e Afonso X ás dos reis precedentes -o primeiro sedente como no caso das imagines de época xelmiriana, o segundo a cabalo coma Fernando II e Afonso IX- tería contribuído a xerar unha percepción de continuidade institucional e de favor rexio ininterrompido dende a inventio dos restos do Apóstolo Santiago. Chama a atención, neste senso, que se substituíse a espada presente nos selos contemporáneos afonsinos por unha lanza que resultaría anacrónica naquela altura, pero que asimilaba figurativamente o Rei Sabio cos reis de León que tanto enxalzaran a sé compostelá. Igualmente significativo é que o documento recolla unha doazón ao arcebispo e aos seus sucesores, especificando que a concesión é «por muchos servicios buenos e grandes que [Juan Arias] me fizo, [...] e porque fallé siempre en él lealtat e uerdat» (Lucas Álvarez 1998: 316-319, doc. 165).

Se a idea de representar o monarca como cabaleiro ben podería deberse ao desexo de afagar un rei que dificilmente podía competir coas fazañas reconquistadoras de seu pai, e a selección do documento tiña a clara intención de recalcar a proximidade entre rei e arcebispo, ningunha das dúas estratexias deu froito á hora de espertar o favor do rei. O propio manuscrito fai visible este fracaso, xa que non se engadirían máis mercés rexias a esta colección. O Tombo A péchase simbolicamente, como lembra Sánchez Ameijeiras (2008: 214), coa copia do signo rodado que iluminaría o privilexio orixinal aquí trasladado (fol. 71r), involuntario recoñecemento de que o Rei Sabio sempre sería unha figura ausente, cuxa vontade só

2 Sobre o proxecto de cabeceira gótica, véxase Puente Míguez (1999). Carrero Santamaría (2014) ten cuestionado ou relativizado o rol de Xoán Arias nalgunhas destas empresas, excepto no relativo ao claustro. 
se faría sentir en Compostela a través da produción da súa chancelaría. O desenlace desta historia é ben coñecido. Os desacordos entre Xoán Arias e o rei por mor da súa arbitraxe no preito que enfrontaba o cabido cos burgueses de Santiago deixaron paso ao enfrontamento aberto (Linehan 1971: 265). O monarca quixo sacar partido da situación de caos xerada tras a morte do prelado interferindo na elección do seu sucesor, o que non foi aceptado polos cóengos composteláns. Nin tan sequera a designación papal de Gonzalo Gómez (1273-1289) puido reconducir o conflito, máis ben todo o contrario, dado vez que o novo arcebispo foi expulsado polo rei, quen privou ademais aos prelados composteláns do dominio sobre a cidade 3 .

Como aventura Joseph F. O’Callaghan (1998: 190-191, 216-217), é posible que un eco desta disputa se perciba nas Cantigas de Santa María, nas que Afonso se intitula «Rei de Castela e de Santiago de Compostela» (c. 367), nunha rima que podería ser non tan arbitraria como parece. É precisamente no terreo das imaxes onde a política anti-compostelá do Rei Sabio se fai explícita, aínda que non é doado determinar se esta estratexia trataba de reconducir o fervor popular cara aos santuarios marianos baixo a protección especial do soberano, polo menos na realidade virtual do manuscrito ${ }^{4}$. Algúns deles, como os de Santa María del Puerto ou a Arrixaca de Murcia, estaban en conexión directa coa política rexia de consolidación e repoboación da fronteira, e outro tanto pode dicirse da elección da advocación de Santa María de España para a súa nova orde militar, destinada á expansión marítima do outro lado do Estreito de Xibraltar (Torres Fontes 1976). No entanto, por forza, habería tamén razóns máis persoais. Da predilección do rei pola Virxe de Villalcázar de Sirga -«logar muy maravilloso» (c. 253)- é mostra a dedicación de catorce cantigas, varias das cales escenifican esta rivalidade coa sede xacobea presentando ao apóstolo baixo unha luz negativa. Foi John E. Keller (1987) quen puxo de relevo este fenómeno, sobre o que teñen insistido outros autores ${ }^{5}$. En todos os exemplos destacados, os protagonistas son peregrinos a Compostela de paso polo santuario palentino, onde son testemuñas dos moi superiores poderes de intercesión da Virxe. É o caso da cantiga 218 -que non chegou a ilustrarse-, na que se narra como un romeiro alemán busca en balde a axuda de Santiago para curar a súa parálise ata que, despois de varias penalidades, é abandonado á porta da igrexa de Villasirga. O contraste non pode ser máis extremo: mentres que o protagonista non só non recuperara a súa mobilidade perante o altar de Santiago senón que perdera a vista tamén, agora, pola contra, a Virxe liberarao de todos os seus males. Por se esta comparación non fose elocuente dabondo, na cantiga 278 (Florencia, BNC, Banco Rari 20, fol. 96r; Fig. 2) o rei trobador exhorta

3 Para unha revisión en profundidade do conflito entre monarca e cabido, resultado da política afonsina de contención dos dominios eclesiásticos, remito ao artigo de Francisco J. Hernández neste mesmo volume.

4 Fronte á temperá protección aos peregrinos que testemuña o doc. 20 do diplomatario galego e a mención de Santiago -«que es nuestro sennor e nuestro defensor e nuestro padre»- no seu testamento (cf. González Jiménez 1991: 549).

5 Véxanse tamén Procter (1951: 29) e Fernández Fernández (2008). 


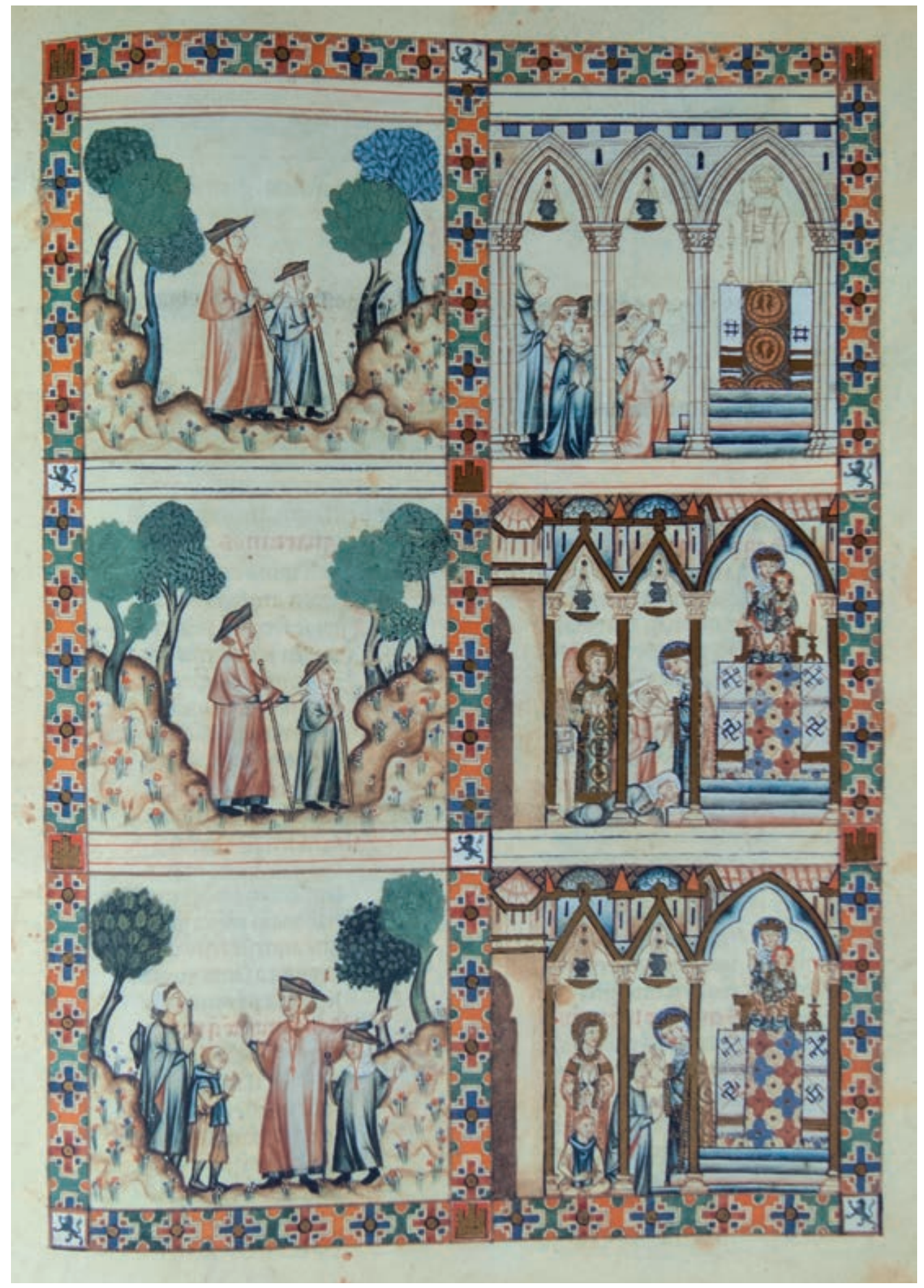

Fig. 2: Afonso X, Cantigas de Santa María. Cantiga 278 (Florencia, Biblioteca Nazionale Centrale, Banco Rari 20, fol. 96r). 
os seus lectores -na voz da súa protagonista- a non visitar a basílica xacobea, xa que só no santuario palentino as súas oracións serán escoitadas: «[...] un ome cego achou / que a Santiago ya; mais ella ll' aconssellou / que fosse por Villa-sirga / se quisesse lum’ aver» (Mettmann 1986: III, 51). Este diálogo aparece representado nas dúas viñetas inferiores da ilustración correspondente, nas que a peregrina -agora recuperada a vista, a diferenza das viñetas superiores- fai acenos a outro romeiro cego que se dirixe a Compostela acompañado do seu guía.

O seu xesto leva a nosa mirada cara á viñeta contigua, onde asistimos á milagrosa curación do peregrino, cuxos ollos volven ter luz pola intervención da Virxe, á vez estatua sobre o altar do santuario e imaxe presente corporalmente. As cores vivas e a duplicación da imaxe mariana parecen expresión do seu poder sobrenatural, ante o cal a estatua monocroma do apóstolo, representado na mesma posición dúas escenas máis arriba, palidece literal e metaforicamente (Fernández Fernández 2008: 89). Máis extraordinario aínda é que se lle atribúa un coñecido milagre xacobeo á Nai de Deus. É o caso da cantiga 175 (Escorial, T.I.1, fols. 231v-232r), na que toda mención á intervención sobrenatural do apóstolo en favor dun mozo inxustamente aforcado en Toulouse cando ía en peregrinación a Santiago é obviada, aparecendo a Virxe como autora do milagre. Elaboración máis temperá desta historia remonta ao Liber Sancti Iacobi e da súa difusión europea é testemuño a súa recompilación no Speculum Historiale de Vicent de Beauvais e, pouco máis tarde, na Lenda Áurea de Jacopo da Varazze, obra case contemporánea do marial rexio (Keller 1987: 72-73). De acordo co relato afonsino, que segue no substancial a tradición xacobea, sería a Virxe a que mantería milagrosamente con vida o romeiro mentres penduraba da forca durante meses, tempo empregado polo seu pai en chegar a Compostela -peregrinación infrutuosa unha vez máis- e volta a Toulouse para recuperar o seu cadáver. Estes exemplos entran en contradición coa visión máis conciliadora presentada por Anthony Cárdenas (2009: 26), para quen as políticas piadosas de Afonso X serían «all inclusive». Porén, á hora de avaliar a relevancia desta polémica en imaxes é preciso abordar o problema creado pola limitadísima recepción do gran marial rexio na vida do Rei Sabio fóra do máis estrito círculo cortesán (cf. Ferreira 2016). Se no caso do Tombo A, o presunto destinatario nunca chegou a ver a súa rexia efixie, é pouco probable que a mensaxe anti-xacobea das Cantigas chegase aos ouvidos do arcebispo don Gonzalo -exiliado na curia- ou á propia Compostela. Dalgún modo, o seu foi un diálogo frustrado e, en último termo, imposible. Neste senso, e dende a perspectiva das artes visuais, a inexistencia de máis obras vencelladas ao monarca en territorio galego ou cunha conexión galega de entre as súas empresas culturais é o máis claro sinal de que o seu mundo e intereses estaban noutro lugar..., certamente en Sevilla, Murcia e Xerusalén, pero tamén as terras do Imperio e o alén do Estreito. 


\section{LIBROS E DOCUMENTOS PARA UNHA RAÍNAA: DOUS TOMBOS COMPOSTELÁNS A CONTRALUZ DA POLÍTICA CASTELÁ-LEONESA}

Fronte a un rei que nunca chegou a visitar a basílica xacobea, pequenos indicios aquí e alá permiten argumentar que Violante ben puido terse desprazado a Santiago ou, polo menos, ser percibida polos seus coetáneos como unha figura máis achegada á Igrexa compostelá, xeográfica e politicamente. Xa no seu estudo do Tombo A, Rocío Sánchez suxería que o fracaso desta empresa puido supor a confección doutro códice de luxo en datas próximas, o chamado Tombo Colorado, do que só se conserva unha copia tardía (Sevilla, Biblioteca Capitular, ms. 82-1-13), dada a coñecer no seu día por José María Fernández Catón (1990). A xulgar por este testemuño, a nova obra debeu de ofrecer unha versión da vella colección documental actualizada aos novos modos e repertorios formais da época, mais con dúas modificacións significativas. Por unha parte, os materiais orixinarios serían reorganizados comezando agora a partir dos documentos relativos a Raimundo de Borgoña e á raíña Urraca (1109-1126), á infanta Urraca e á súa irmá Elvira. Esta escolla revelaría que quen estivese ao cargo «comprendía todavía la estructura de la doble genealogía que gobernaba la ordenación de la primera parte del Tumbo A», unha dupla xenealoxía institucional -doazóns rexias e do Infantado- que confluían precisamente na raíña Urraca, infanta e logo raíña de León e Castela (Sánchez Ameijeiras 2009a: 67). Por outro lado -e este detalle é máis relevante aínda para o que aquí se trata-, todas as infantas e raíñas serían representadas con coroas no Tombo Colorado, a diferenza do que sucedía no seu referente, onde só Urraca merecía este tratamento. Máis que un problema de comprensión das realidades do Infantado, daquela xa desaparecido, este ascenso das mulleres rexias en termos simbólicos podería deberse, en opinión de Sánchez Ameijeiras (2008: 216), ao desexo de «invocar unos ojos femeninos como posibles espectadores privilegiados del nuevo códice: los de la entonces reina de Castilla Violante de Aragón».

Pouco se sabe acerca do padroádego exercido pola raíña Violante, para alén da fundación clarisa de Allariz e do seu apoio á Orde Franciscana, aínda que varios aspectos poderían apuntalar esta suxestiva hipótese. En primeiro lugar, parece moi probable que ela fose a comitente do Officiumet Vita S. Elisabeth Landgraviae Thuringiae (Paris, Bibliothèque nationale de France, N.A.L. 868), como argumentei noutro lugar ${ }^{6}$. Ora ben, a esta obra haxiográfica dedicada a honrar a memoria de Santa Isabel de Hungría, medio irmá da súa nai, e destinada probablemente á capela baixo a advocación da santa na catedral de Sevilla, poderían engadirse outros manuscritos. Dispersos no rexistro documental destas décadas atopamos dous textos que permi-

6 Remito a Rodríguez Porto (2012: II, 7-39). Cf. Avril (1983: 82, n.o 94, ils. XLVIII, CVIII e F); Joneitis/ Blume (2007) e Joneitis (2008). 
ten afirmar a familiaridade da raíña co mundo dos libros, á parte das grandes obras auspiciadas polo seu home. O primeiro deles é unha carta datada en 1272 e destinada ao freire Diego de Rois, na que se lle reclama en nome do seu irmán Sancho, arcebispo de Toledo, a devolución dos libros que pertenceran a don Lope, bispo de Sigüenza. Ao ver que o franciscano rexeitaba a entrega dicindo que as obras eran en realidade un depósito da raíña Mencía († 1270), viúva de Sancho II de Portugal, Violante responderíalle con retranca: «fray Diego, bien sabedes que tales libros como aquellos non serien de la Reyna» (Rubio García 1985: 550). A soberana tiña claro, xa que logo, cales eran os libros que conviñan a unha raíña e cales non formarían parte da súa biblioteca; neste caso, libros de natureza teolóxica e xurídica. Con todo, iso non significa que Violante non soubese manexarse no complexo mundo da lexislación castelá e leonesa. Proba diso é que, segundo se le nun rexistro dos libros pertencentes no seu día ao Marqués de Montealegre (1677), a raíña tería entregado aos veciños de Talavera unha copia ilustrada do Fuero Juzgo con «Retratos de todos los reyes Godos de España» (Rodríguez Moniño 1950: 457).

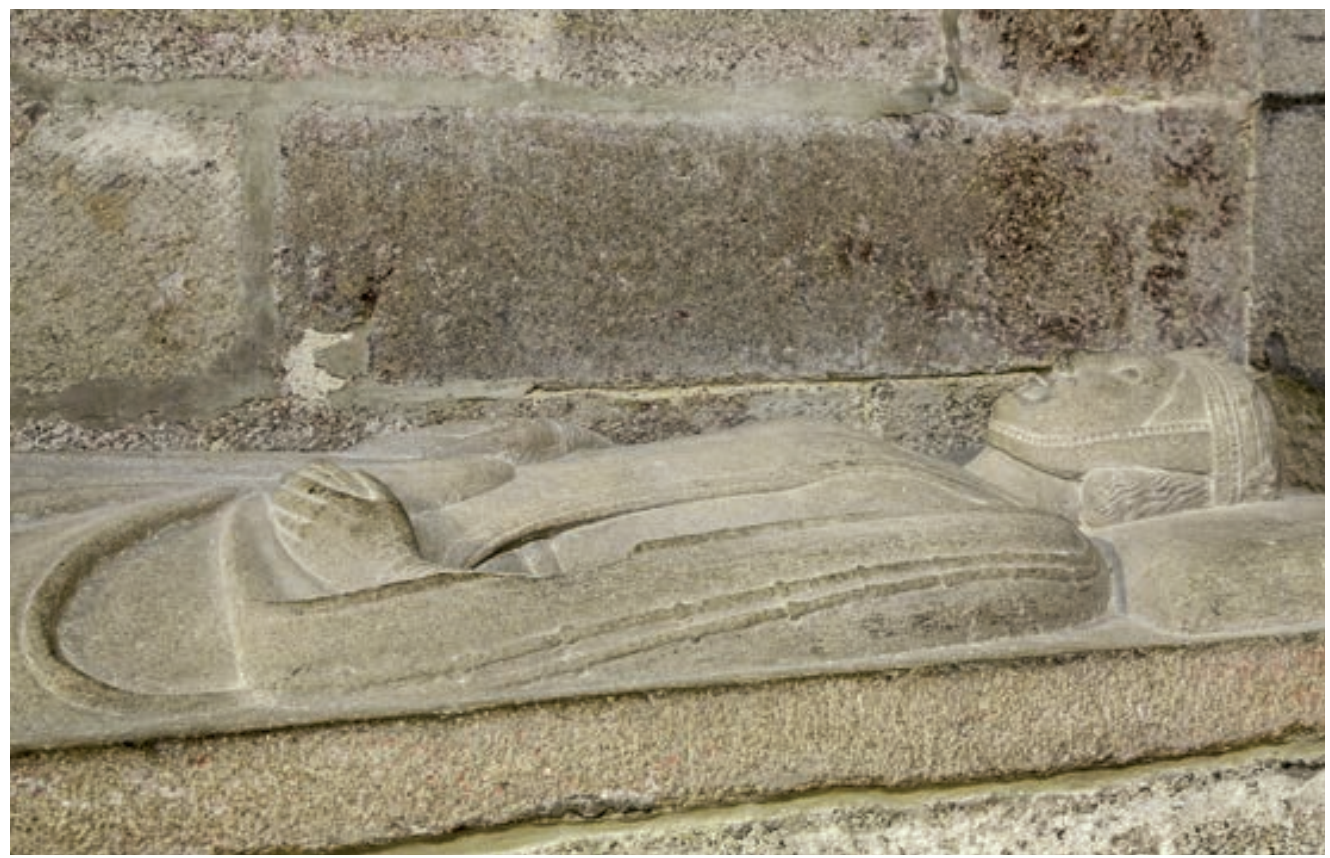

Fig. 3: Tumba da raíña Berenguela de Aragón (†1147). Catedral de Santiago de Compostela. 
Sánchez Ameijeiras sitúa a copia e ilustración do novo cartulario entre 1253, data da derradeira concesión copiada a partir do modelo, e 1263, ano do último documento copiado. Tamén contra a década de 1260 debeu de procederse á renovación do panteón rexio compostelán, coa labra dunha efixie xacente (Fig. 3) para a raíña Berenguela († 1149), muller de Afonso VII e filla de Ramón Berenguer III. A innegable oportunidade desta iniciativa, ao coincidir coa chegada ao trono castelán dunha segunda raíña do veciño Aragón, parece apuntar na mesma dirección. Tanto esforzo por parte de Xoán Arias e do cabido compostelán, nos mesmos anos en que o Rei Sabio non acababa de poñerse do lado da Igrexa de Santiago no seu preito cos burgueses da cidade, invita a pensar que, efectivamente, se estaba a procurar o amparo de Violante. Esta posibilidade encaixaría coa información fornecida por certos cronistas franciscanos do século XviII, que atribúen a fundación do convento de Santa Clara de Santiago polas mesmas datas á mesma soberana. Se ben esta afirmación foi desmentida de modo categórico por José García Oro (1988: 121-123), podería conter algo de verdade. Aínda que a fragmentaria documentación conservada non permite confirmar que a raíña visitase Compostela, o certo é que Violante viaxou polo reino de León entre o outono de 1264 e o inverno de 1265, ao ser nomeada polo seu home lugartenente deste territorio, precisamente para arbitrar certos conflitos locais nos que colidían -como en Compostela- a xurisdición municipal, eclesiástica e rexia ${ }^{7}$ Tamén en 1264, a raíña despregaba toda a súa capacidade mediadora na resolución doutro conflito legal, atendendo ás queixas presentadas polos concellos de Estremadura a propósito da aplicación do Fuero Real afonsino no lugar do tradicional Fuero Juzgo. E, de modo aínda máis visible, contribuía a afogar a revolta dos mudéxares en Murcia ao conseguir que seu pai Jaume I e Afonso X resolvesen as súas diferenzas, garantindo o indispensable apoio aragonés que o seu home precisaba (Fuente Pérez 2017: 135-136; González Jiménez 2004: 158-161, 176-181). A estratexia compostelá de procurar a axuda da raíña non ía desencamiñada e contaba con alentadores precedentes.

Pola contra, a concesión en 1294 do vello código visigodo aos habitantes da súa vila de Talavera, á que me referín antes, sitúanos nun contexto político diametralmente oposto, unha vez desencadeado o preito sucesorio, un ambiente en que se encadraría tamén a confección doutro códice compostelán que podería ter como destinataria implícita a Violante. Trátase do Tombo de Toxos Outos (Madrid, Archivo Histórico Nacional, códices L. 1002-B), copiado e ilustrado cara a 1289 a instancias do abade Sancho Eanes ${ }^{8}$. Como é sabido, o mosteiro de San Xusto de Toxos Outos dependía da Igrexa de Santiago dende a súa fundación como eremitorio polos nobres Froila Afonso e Pedro Muñiz, autorizada polo arcebispo Xelmírez. A influencia do modelo catedralicio é patente na decisión de incluír imaxes dos reis e raíñas

7 Debo esta información á xenerosidade de Francisco J. Hernández, cuxo futuro traballo sobre Violante botará luz, sen dúbidas, sobre os aspectos da biografía da raíña que permanecen aínda na escuridade.

8 Unha nota moderna escrita no volto do primeiro folio de garda antigo indica: «Scribere fecit domnus Sancius, abbas Sancti Iusti, era M CCC XXVII, quinto kalendas maarci» (Pérez Rodríguez 2004: 19). 


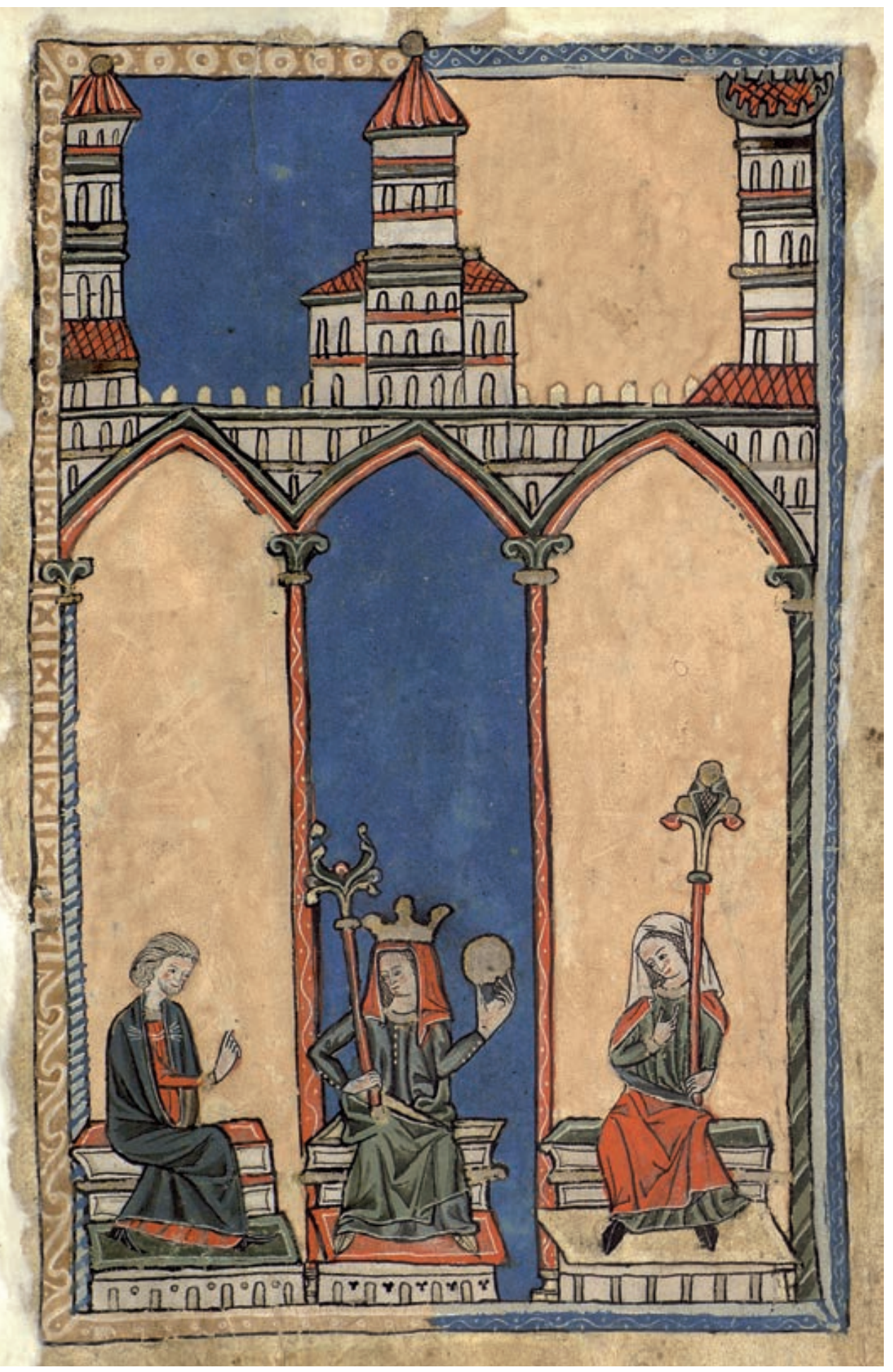

Fig. 4: Dona Teresa de Portugal, acompañada da súa filla Urraca Enríquez e o home desta, Vermudo Pérez de Traba. Tumbo de Toxos Outos (Madrid, Archivo Histórico Nacional, códices L. 1002-B, fol. 6v). 


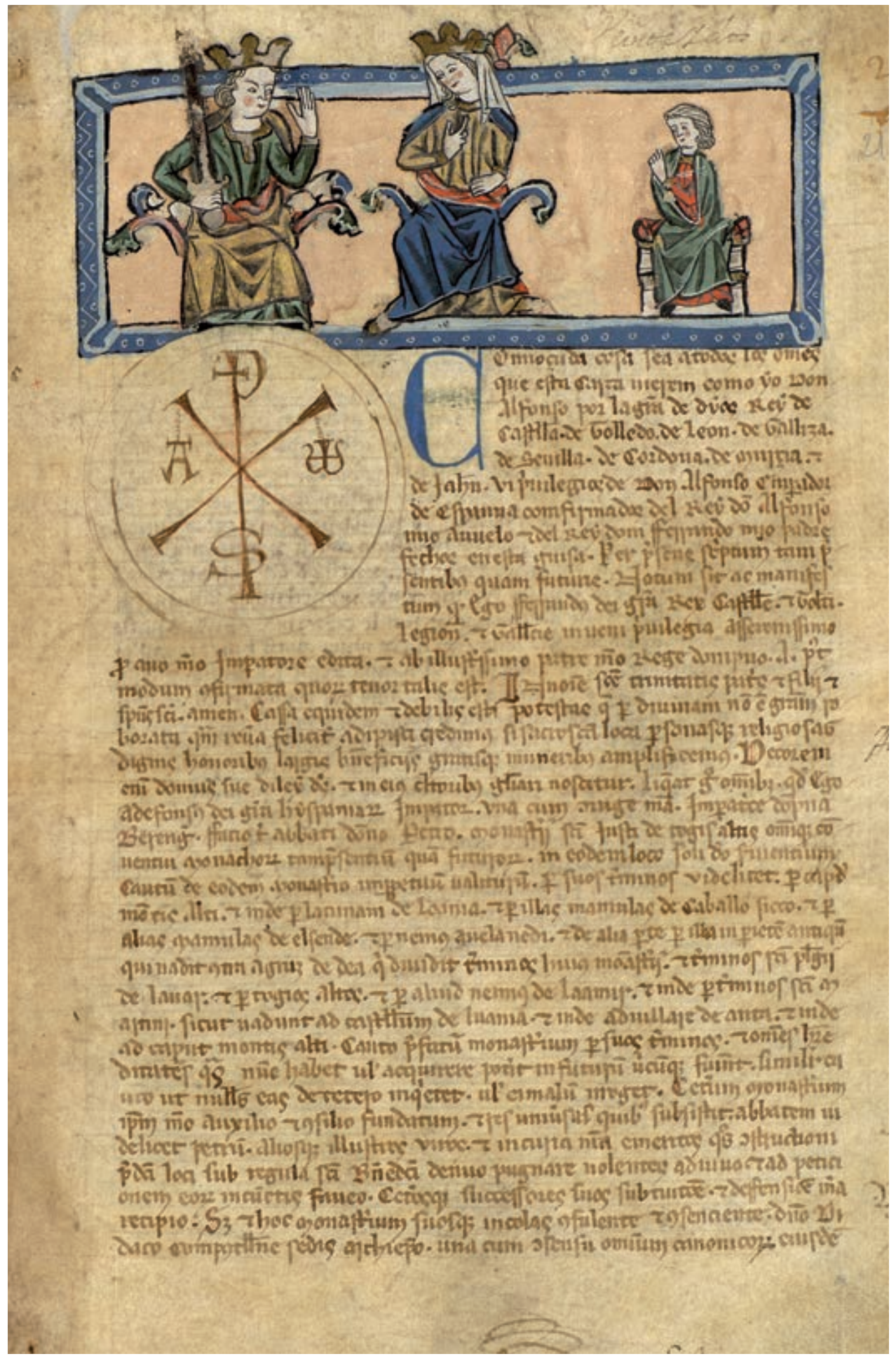

Fig. 5: Afonso X, Violante de Aragón e Fernando da Cerda. Tumbo de Toxos Outos (Madrid, Archivo Histórico Nacional, códices L. 1002-B, fol. 21r). 
mencionados na documentación nel compilada. Ao igual que no Tombo A e o Tombo Colorado, as raíñas ocupan nesta obra un lugar privilexiado, xa que aparecen en catro das sete ilustracións que se inclúen no manuscrito. Así, dona Teresa, futura raíña de Portugal, é efixiada acompañada da súa filla Urraca Enríquez e do home dela, Vemudo Pérez de Traba (fol. 6v; Fig. 4), Urraca de Portugal figura xunto a Fernando II (fol. 9v), e o mesmo Berenguela de Castela xunto a Afonso IX (fol. 26r). A propia Violante comparece acompañando Afonso X e o seu fillo Fernando de la Cerda (fol. 21r; Fig. 5), representado como o neno que era no momento en que se emitiu o documento. Esta disposición traduce visualmente as fórmulas de outorgamento dos documentos copiados a continuación, das que só transcribirei aquí a correspondente á miniatura en que aparecen os nosos protagonistas: «Et yo, sobredicho rey don Alfonso, regnante en uno cun la reyna donna Yolant, mi mugier, te cum myo fijo don Fernando en Castella et en Toledo, en Leon, en Galliza, en Seuilla, en Cordoua, en Murcia, en Jahen, en Baeza, en Badalloz et en el Algarue, otorgo este priuilegio et confirmolo». Emporiso, a rareza da representación de rei e raíña xuntos -os paralelos son contados- podería ser indicativa, quizais, de que o rol feminino ía máis aló da simple confirmación da vontade dos seus esposos, ou que así o percibían os que deseñaron as ilustracións do Tombo de Toxos Outos ${ }^{9}$.

Neste senso, convén lembrar que se trata dun ciclo pictórico selectivo, pois coa excepción da primeira miniatura dedicada aos fundadores do cenobio e ao arcebispo Xelmírez (fol. 1r), só se ilustran documentos reais, que constitúen unha minoría en comparación coas doazóns e concesións realizadas pola nobreza local. É máis, nin sequera foron efixiados todos os monarcas que aparecen no tombo como protectores do mosteiro, constatándose a paradoxal ausencia de Afonso VII, talvez o soberano máis estreitamente vencellado a Toxos Outos. En cambio, represéntase a dona Teresa (Fig. 4) en tanto que sogra de Vermudo Pérez de Traba, que é quen outorga o documento. Como xa advertira Ghislaine Fournés (2008: §19), a condesa ocupa o lugar central da composición e aparece coroada, portando cetro e orbe, se ben non era raíña de Portugal naquela altura. O Conde de Traba, pola contra, queda desprazado cara á esquerda, desprovisto de calquera insignia de poder. Non é esta a única instancia en que as raíñas mostran un status similar ou mesmo superior ao dos seus consortes e familiares. Dáse a circunstancia, por exemplo, de que o trono en que se asenta a raíña Urraca é máis grande e máis alto que o do seu home Fernando II, un detalle que non puido ser froito do azar. Outro tanto sucede coa efixie da raíña dona Berenguela, quen, ao dispor o seu trono sobre un estrado, consegue impor a súa presenza sobre a do seu esposo Afonso IX.

9 Só dous exemplos, coetáneos, veñen á mente: a representación de Sancha de Castilla xunto a Afonso II de Aragón no Liber Feudorum Maior (Barcelona, ACA, Cancillería, Registros, n.o 1, fol. 93r; 1192) e a de Leonor de Inglaterra con Afonso VIII no Tumbo Menor de Castilla facendo doazón da vila de Uclés á Orde de Santiago (Madrid, AHN, cód. 1046-B, fol. 15r). 
A ilustración correspondente a Afonso X e Violante (Fig. 5) sería aínda máis sutil na súa redefinición do papel da raíña en relación co rei. El porta unha espada, ela un cetro, emblemas ambos das súas respectivas xurisdicións, é dicir, do poder para facer e facer cumprir a lei. Ao seu carón, represéntase o herdeiro, no que se fundirían as súas liñaxes (Prado Vilar 2009: 220, n. 67). Violante comparece, xa que logo, en calidade de raíña, esposa e nai, e o seu propio xesto, chamando a atención sobre a súa persoa, parece destinado a lembrarlles tanto ao seu home coma ao espectador o seu papel na xestación do herdeiro e a perpetuación da dinastía castelá-leonesa.

Se no Tombo Colorado crin ver a pegada da presenza de Violante en León contra 1264, a data máis tardía do Tombo de Toxos Outos déixanos en terreo máis sólido, posto que para entón a súa actividade -potencial ou real- en Galicia vén referendada polo rexistro documental. En 1289 o convento de Santa Clara de Allariz era xa, como veremos, unha realidade institucional, polo menos no papel, xa que se procedera á compra dos terreos onde se levantaría a súa fábrica, e Sancho IV aprobara a súa xurisdición (García Barriuso 1990: 18-19). No ano de 1286, cando se concedían estas mercés a Allariz, o rei estaba en Galicia, pero resulta moi pouco probable que a produción do cartulario noiés se concibise para preservar a memoria desta visita e estimular o favor do Bravo. O prominente lugar acordado ás soberanas e, en particular, o xesto desafiante de Violante non encaixan ben con este escenario, tampouco que ningún dos documentos copiados corresponda ao seu reinado. De facto, non se lle escaparía á audiencia do cartulario a anacrónica representación de Fernando de la Cerda, case quince anos despois do seu pasamento e cando seu irmán xa reinaba, contravindo o estipulado por Afonso X no seu testamento. Non podo evitar pensar que esta imaxe encerra máis dunha clave para entender a tortuosa relación entre Violante e Sancho, e os efectos deste drama familiar non só no destino do convento allaricense senón tamén do reino de Galicia ata que Afonso XI, bisneto de Afonso X e Violante, se fixese co poder.

\section{O CONVENTO DE SANTA CLARA DE ALLARIZ E O SEU TESOURO: PADROADO, MEMORIA E PREITO DINÁSTICO}

O 18 de xullo de 1292 o cardeal Matteo d'Aquasparta comunicoulles aos franciscanos da provincia de Santiago e ao gardián e lector da Orde en Ourense que se outorgara licenza á «excelentísima dona Violante, raíña de Castela e León» para a fundación do convento de Santa Clara de Allariz. A propósito deste documento, razoaba con meridiana claridade Mercedes Durany que a dita licenza tivo que ser solicitada con anterioridade a esta data. Polo tanto, a esta petición non sería alleo o 
feito de que o 21 de abril dese mesmo ano se reuniran as Cortes de Valladolid, nas que se depuxo a Afonso X e se outorgou a rexencia ao infante Sancho, «con el apoyo de los señores eclesiásticos gallegos y la nobleza del reino» (Durany Castrillo 2009: 138; véxanse tamén Linehan 1997: 137-138 e Katz 2015: 814-816). Así a todo, non mencionaba esta autora que nesta altura a vila de Valladolid estaba aínda nas mans de Violante e que o seu apoio sería decisivo nesta primeira fase da revolta. Por se quedase algunha dúbida sobre os sentimentos da soberana, a Crónica de Afonso X (González Jiménez 1998: 223) confirma a sospeita: «Et plaziél mucho por esta boz que tomara [Sancho] contr el rey don Alfonso, su marido». Non fora sempre así, e a propia historia da fundación allaricense daría motivos a nai e fillo para futuros enfrontamentos.

Fíxose referencia antes á compra dos terreos onde se erixiría o convento e á concesión do privilexio de couto a Santa Clara por parte de Sancho IV en 1286, a petición de súa nai. No entanto, é preciso lembrar que na mesma visita a Galicia na que se emitiron eses documentos, o novo rei designou tamén aos prelados das sés de Compostela e Ourense, respectivamente o dominico Rodrigo González (1286-1304) e o temible Pero Eanes de Novoa (1286-1308), que acabaría por se converter no peor inimigo dos franciscanos na provincia. ¿Descoñecía Sancho que puxera un lobo a termar do rabaño materno? Con independencia da resposta que deamos a esta cuestión, o certo é que o apoio que lle prestaba o prelado ourensán debía de ser demasiado importante como para perdelo, aínda que este último se negase a consagrar a fundación da súa nai e non autorizase a inhumación na igrexa do convento ${ }^{10}$. Non sería ata 1294 cando se celebrou a consagración do templo, se ben oficiada polo bispo dominico de Silves (Portugal), Domingos Soares ${ }^{11}$. E se, por unha banda, Sancho non aforraría xestos de favor cara ao convento das clarisas, o futuro da fundación quedaría seriamente comprometido en 1288 pola decisión de retirarlle á súa nai o control sobre as máis ricas vilas que formaban parte do seu dote -Valladolid, Plasencia, Ayllón, Astudillo, Curiel, San Esteban de Gormaz e Béjar- para entregalas á súa muller María de Molina (Kinkade 1992-1993: 14). Neste senso, e aínda que a historiografía previa veña dicindo o contrario, acerta Melissa R. Katz (2013: 56-57) ao sinalar a relativa pobreza das mandas de Violante no seu testamento de 1292, no que ordena ser enterrada «en esse monesteyro de allariz que yo ffago dela orden de santa clara en derecho del altar de sancta maria dentro del coro de las duenas $\gg^{12}$.

Esta circunstancia podería explicar o durísimo ton en que está redactado este documento, onde a raíña lle esixe ao seu fillo «por la bendiçion de su padre

10 Nótese que, en 1303, os freires de Ourense aínda estaban acollidos en Allariz (García Oro 1988: 141).

11 Madrid, AHN, Clero Secular-Regular, carp. 1429, n.․ 10. Publicado por López (1927: 29-30) e García Barriuso (1990: 35-36). Este documento está dixitalizado en PARES: http://pares.mcu.es/ParesBusquedas20/catalogo/description/5861428 [última consulta: abril 2021].

12 Madrid, AHN, Clero Secular-Regular, carp. 1429, n.o 5. Publicado por Castro (1722: I, 324-327), López (1927: 15-18) e García Barriuso (1990: 25-28). Presento aquí a miña transcrición do documento. Tamén está dixitalizado en PARES: http://pares.mcu.es/ParesBusquedas20/catalogo/description/4896826 [última consulta: abril 2021]. 
et de su madre» que non lle retire o dominio dos lugares que aínda estaban no seu poder ata que as súas disposicións sexan cumpridas, e mesmo que «por la bendiçion de dios et de sancta maria premera mjente et dessi por la de su padre et su madre» non embargue nin desapodere os seus executores testamentarios. De facelo, Violante ameaza: «demandegelo dios et sancta maria su madre enel cuerpo et enel alma et en todas las cossas que del fueren et lo quela mj alma lazrare por ello demandegelo dios en la suya et nunca gelo perdone». As súas palabras non parecen expresión dunha fonda relación materno-filial, nin sequera dunha interesada alianza nai-fillo, como recentemente argumentou María del Mar Graña Cid (2019: 75) ${ }^{13}$.

Talvez a ambigüidade da representación de Violante e Fernando de la Cerda no Tombo de Toxos Outos (Fig. 5) respondese non só ao afastamento entre Sancho IV e súa nai, senón tamén á crecente desafección de moitos dos nobres e eclesiásticos galegos que apoiaran o infante en 1282 e que, naquela altura, comezaban a mostrar a súa preferencia polo infante Xoán (Gaibrois 1922-1928: I, 156). Que as cousas non melloraron coa morte de Sancho en 1295 pode comprobarse lendo outro documento, datado a finais de setembro dese ano en Medina de Rioseco -é dicir, dous meses despois das Cortes de Valladolid polas que se recoñeceron aos diversos titores que se repartirían o poder durante a minoría de Fernando IV-, no que Violante reitera a súa vontade de entregar todos os seus bens ao convento de Allariz, os que tiña nesa altura e os que tería no momento da súa morte. De novo, a linguaxe da raíña é ameazante, dirixindo agora a súa maldición non só contra o novo rei mais tamén contra calquera -«fijos nin nietos nin heredero que yo aya»- que fose quen de oporse aos seus designios ${ }^{14}$. Por iso sorprende a lectura que del fai Katz (2013: 59), que ve nestas palabras «an attempt at reconciliation or, at least a stoic truce, between the two widowed queens». Tal afirmación contradise coa estampa que presenta a Crónica de Fernando IV, dos primeiros meses de 1296, cando María de Molina tivo que facer fronte á conxura do infante Xoán e de Afonso de la Cerda coa intención de dividir entre eles o reino castelán-leonés, así como á declaración conxunta de guerra por parte dos reis de Portugal, Aragón, Francia e Granada en apoio das pretensións do infante de la Cerda (Gaibrois 1936: 102-112). O papel de Violante nesta ofensiva non foi menor, aparecendo visiblemente ao lado do infante Xoán, proclamado rei de León, Galicia e Sevilla en abril dese ano, co apoio de boa parte da nobreza galega e dos seus prelados, entre eles o bispo de Ourense (Linehan 1997: 141-142). É neste contexto no que a vella raíña, que nunca perdera a esperanza de recuperar as súas antigas posesións -se ben

13 Como sinala María Jesús Fuente (2017: 159), «Violante desconfiaba de su hijo, y Sancho desconfiaba de su madre, tenía buenas razones para hacerlo».

14 «Et qual quier que contra ello fuere aya la yra de dios e la mi maldiçion que nunqua pueda seer saluo por cosa que diga nin que faga» (transcrición miña). Ourense, Arquivo Histórico Provincial de Ourense (AHPOu), Allariz, carp. 6, n.ํㅡㄹ. Nin Atanasio López nin Patrocinio García Barriuso transcriben este documento, aínda que alude a el Olga Gallego (1986: 45). Agora pode consultarse en GALICIANA: http:// arquivo.galiciana.gal/arpadweb/es.ga.32054.ahpou/es/catalogo_imagenes/grupo.do?path=1855 [última consulta: abril 2021]. 
non semellaba confiar en ningún dos seus novos aliados-, tratou pola forza de entrar en Valladolid. Ao ver que se lle negaba o paso, «fue muy sannuda e amenazolos de muerte» (Benítez Guerrero 2017: 27).

Non é este lugar para matinar se Violante tiña unha «inveterate tendency to conspiracy» ou se os seus innegables dotes políticos poderían tela convertido nunha outra Berenguela se as circunstancias lle fosen máis favorables ${ }^{15}$. Porén, en calquera caso, os recentes intentos de rehabilitar a súa figura non deberían apagar os trazos incómodos da personaxe que retratan os documentos e testemuños contemporáneos -algúns, como vimos, mesmo autógrafos-, e que nos falan dunha muller astuta, fascinante e remisa a abandonar a posición de poder e privilexio que, non sen motivo, cría que lle pertencía. Baixo a luz da evidencia aquí presentada, coido que Santa Clara de Allariz foi moito máis que un simple «spiritual and emotional refuge» (Katz 2015: 819) para Violante en tanto que fundación que aspiraba a ser o novo panteón rexio dun territorio que, durante estes anos, a piques estivo de desligarse da coroa castelá baixo o infante Xoán ${ }^{16}$. Para ponderar o seu valor en termos xeopolíticos, convén engadir, ademais, a proximidade do convento á fronteira portuguesa e a súa favorable localización a carón da Vía da Prata, un dos eixes principais de articulación peninsular (Graña Cid 2019: 74). Este vínculo teríase reforzado polo feito de que a provincia franciscana de Santiago -cuxo provincial Frei García Blandes († 1332) aparece como fiduciario no testamento da raíña, da que era confesor, e sería enterrado en Allariz- exercería a súa xurisdición sobre terras portuguesas ata 1415. Por se todo isto non fose suficiente, dende 1282, unha princesa aragonesa -a súa sobriña Isabel- reinaba no país veciño. As dúas coincidiran brevemente durante a estadía de Violante na corte de seu irmán Pere III, como se lembra na vita da rainha santa, escrita pola súa sucesora Isabel de Cardona ${ }^{17}$. Aínda que non é posible afirmar a relevancia deste feito na elección de Allariz para a fundación rexia, pola contra a influencia determinante do convento allaricense na futura creación de Santa Clara de Coimbra por Isabel de Portugal en 1314 está fóra de toda dúbida ${ }^{18}$.

A comparación coa súa sobriña, aparentemente tan afastada da súa belicosa tía, revela afinidades insospeitadas que, pola súa vez, lle outorgan outros matices á actividade de patrocinio de Violante. A máis destacada destas coincidencias é que as dúas preferiron enterrarse nas súas respectivas fun-

15 A cita é de Linehan (1997: 138). Sobre o proxecto de rexencia con Fernando de la Cerda, tal e como pode adiviñarse na chamada Crónica del alboroço, véxase Hernández (2015).

16 Cf. tamén Fuente Pérez (2017: 184) sobre o valor político da fundación; e Graña Cid (2019: 75) sobre o xeito no que a raíña foi quen de poñer a Orde Franciscana ao seu servizo.

17 « [D]izia esta Rainha Dona Isabel, que se acordaua que em leuando Exrey Don Iames para Poblete, hu elle escollera sa sepultura, que vira ir em pos el dous Reys seus filhos, \& tres Rainhas; as quais eraõ a madre desta Dona Isabel, \& et a Rainha Dona Violãnte, que foi mulher delRey Dom Affonso filho delRey Dom Fernand, que filhou Seuilla aos Mouros, \& a outra Rainha era mulher del Rey Dom Iames, a que ficaua o Reyno de Maorgas» (Brandão 1980: VI, 496b-497a). Este traslado acontecería en 1278.

18 Este aspecto xa fora tratado en Rodríguez Porto (2011: 43-68). Véxanse García Oro (1990: 116-117) e agora Graña Cid (2019: 74-75), quen insisten na relación destes dous conventos coas clarisas de Zamora. 
dacións clarisas, lonxe dos lugares escollidos polos seus maridos ${ }^{19}$. Non menos importante é que tanto Violante como Isabel fixeran da súa relixiosidade franciscana unha sorte de devoción dinástica. Este aspecto pode percibirse especialmente ao cotexar o testamento da primeira cunha carta escrita pola segunda:

donna Yolant por la gracia de dios rreyna de Castiella et de Leon, en mjo sano entendimiento qual mele dios dios [sic], et en mj cunplida memoria et en mj salut con mj buena voluntad et con grant deuoçion, por mucho bien et mucha merçet que me dios ffizo et sennalada mjente por muchos et muchas de mjo linage que ffizo acabar su vida et su ffazienda en grant omillat et con sancta religion. Otorgo et prometo de tomar la orden de Sancta Clara enel monesterio de allariz que yo ffago et quando melo dios guisare a mj onrra et aquella del monesterio, a loor de dios e de Sancta Maria ssu madre et de Sancta Clara, et de acabar enella mj vida ${ }^{20}$.

nós Dona Isabel mulher em outro tempo do muito alto, \& muy nobre Rey, \& Senhor D. Diniz [...]: avendo feusa em nosso Senhor Jesu Christo, \& na Virgem Santa Maria sá Madre, \& na Corte Celestial, \& avendo devoçom na Ordem de Santa Clara, como sempre aquelles, \& aquellas onde nos vehemos, aviamos posto em nossa vontade, que se acontecesse que nós moressemos antes que o dito Rey D. Diniz nosso marido lidimo, que aviamos devoçom de morrer no avito de Santa Clara (Ribeiro de Vasconcelos 1894: 10)

Non queda moi claro se a raíña de Castela facía alusión a santa Isabel de Hungría, medio irmá de súa nai, ou á súa propia irmá, a infanta Sancha, finada en Terra Santa con sona de santa, de acordo co que relata don Juan Manuel no seu Libro de las armas (Jaspert 1997). No caso de Isabel de Portugal, podería estar evocando a memoria da súa nai, Constanza de Sicilia, gran protectora dos franciscanos, así como a da súa avoa Violante de Hungría e, por suposto, a da propia Violante de Aragón. Neste senso, débese insistir na especial vinculación entre a Casa Real de Aragón e a Orde Franciscana, moito máis marcada que no caso da familia real castelá, o que facería das clarisas a opción natural tanto para a raíña Violante como para a súa sobriña en Portugal, rompendo coa secular preferencia polos cistercienses en ambos os dous reinos (Katz 2013: 55) ${ }^{21}$. Proba desta consciente asimilación entre a súa orixe aragonesa e a protección das clarisas é que as dúas uniran, dun xeito ou doutro, a exaltación

19 D. Dinís se fixera enterrar no mosteiro cisterciense de Odivelas.

20 Coma na nota 12.

21 Sobre o padroádego da Orde Franciscana en Aragón e Castela, remito a García Oro (1990), Webster (1993), Gutiérrez Baños (2017: 283-296), Cendón/Fraga (2017: 341-345) e Graña Cid (2019). 
de santa Clara de Asís como fundadora da orde feminina coa de Isabel de Hungría, membro da súa propia beata stirps, reivindicada orgullosamente por Violante no seu testamento ${ }^{22}$. Así, a bula Licetis, datada o 13 de febreiro de 1291, concedía indulxencias a quen visitase Santa Clara de Allariz polo Nadal e polas festas da Anunciación, Purificación e Asunción, ademais dos días dedicados a san Francisco, santa Clara, santo Antón e santa Isabel de Hungría ${ }^{23}$. Isabel, pola súa parte, non deixará de referirse a Santa Clara de Coimbra no seu segundo testamento, escrito en 1327, como «meu mosteiro de Sancta Clara e Sancta Izabel» (Sousa 1793: I, 117 e 119, n.o 16), e incluirá unha imaxe da santa turinxia no seu nomeado sepulcro pétreo ${ }^{24}$.

Sen facermos máis fincapé na comparación entre as dúas raíñas, que daría moito xogo noutro lugar, non quixera deixar de insistir noutro punto común entre elas, a súa predilección por imaxes da Virxe e o Neno, da que son exemplo tanto a Virxe abrideira allaricense (Fig. 6) como a luxosa imaxe en prata sobredourada que hoxe se conserva no Museu Machado de Castro (inv. 6034), ambas son doazóns ás súas fundacións respectivas ${ }^{25}$. Así a todo, se no caso da raíña portuguesa son varias as obras de ourivaría e xoias que poden atribuírse ao seu patrocinio, entre as pezas conservadas en Santa Clara de Allariz só cómpre relacionar a mencionada Virxe en marfil á iniciativa de Violante, pois é a única cuxa cronoloxía encaixa no arco temporal da súa vida, como tratarei de argumentar a continuación. Obra mestra da eboraria medieval e das máis icónicas da arte medieval hispana, certamente digna dunha raíña, moito se ten escrito sobre esta peza, tanto para determinar o seu lugar de produción coma para explicar a súa orixinal tipoloxía, para a que se poden citar moi poucos paralelos, en boa medida por recibir a censura do Concilio de Trento ${ }^{26}$. De especial interese para este traballo é a hipótese presentada por Rocío Sánchez Ameijeiras (2009b: 364-365), para quen este tipo de imaxes, que se abren para a contemplación dos Gozos de María tallados no seu interior, poderían ser concibidas en resposta ás sofisticadas miniaturas despregadas nos «Códices das Historias» das Cantigas de Santa María, así como nas reflexións poetolóxicas e cuestións de retórica visual xeradas polo proceso de ilustración do marial rexio.

En realidade, nin sequera é posible determinar que pezas da capela privada de Violante serían entregadas ao convento, ou mesmo se as súas derradeiras vontades serían respectadas, xa que no seu testamento non se detalla o contido da súa doazón e non coñecemos inventarios medievais nos que se consigne a orixe do

22 En xeral, sobre a noción de beata stirps, véxanse Vauchez (1977), Hoch (1992) e Klaniczay (2002).

23 Segundo Jacobo de Castro (1722, I, 328), a bula Licet is estaba custodiada no arquivo do convento. Porén, non se conserva traza dela. Atanasio López publicáraa en 1927 a partir do Bullarium Franciscanum (IV, p. 218). Véxase García Barriuso (1990: 24).

24 Sobre o túmulo, véxase Pato de Macedo (1999).

25 Sobre esta última, véxase Domenge/Molina (2009).

26 Remito aos traballos de Sánchez Ameijeiras (2009b: 364) e Katz (2012) para unha avaliación da historiografía precedente. Todos os autores que se ocuparon dela dataron esta obra no último terzo, máis precisamente no último cuarto do século XIII. 


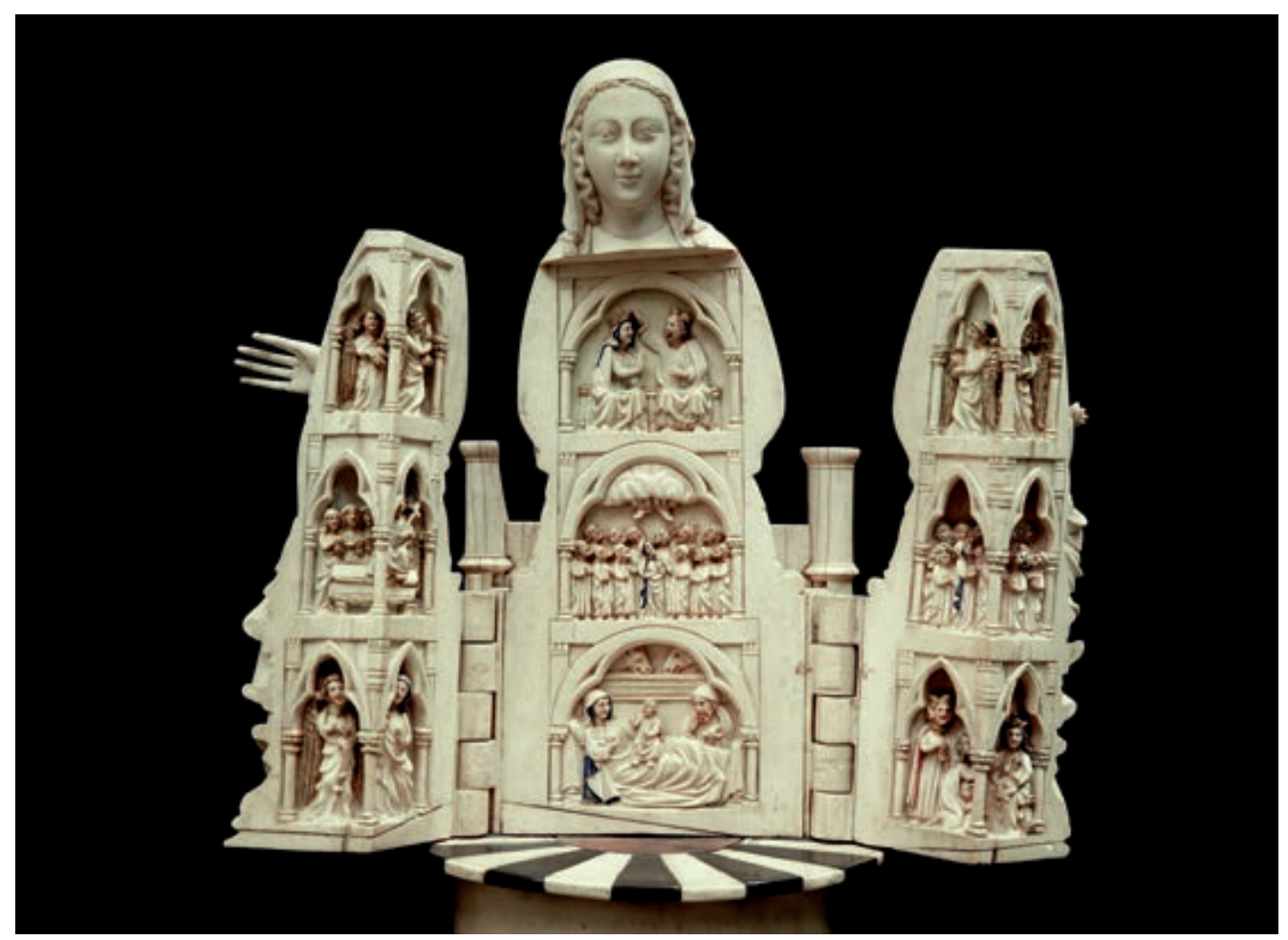

Fig. 6: Virxe abrideira (Real Monasterio de Santa Clara de Allariz).

legado que hoxe conservamos. Maiores problemas presenta aínda a azarosa historia posterior do tesouro allaricense, xa que a fábrica medieval foi arrasada polo lume en 1758, momento en que deberon de perderse tamén algúns dos preciosos obxectos que alí se conservaban dende a Idade Media. Entre as obras superviventes, as intervencións tardías e non sempre afortunadas contribuíron tamén a desfigurar o conxunto, así como a desorientar os escasos investigadores que ocuparon del $^{27}$. Pero, vaimos amodo, separando o gran da palla e tratando de presentar esta maraña de forma intelixible. No seu testamento, Violante indica que 4000 marabedís terán que ser entregados ás monxas para adquirir os libros que precisaren, e que elas serán as destinatarias de «mio lecho [et] toda mj ropa», además de «toda mj capiella assi que les yo di commo lo que yo tengo». Destes asertos pódese deducir que antes de 1292, e cando o convento aínda estaba en construción, a raíña xa fixera entrega dalgún obxecto da súa capela. Considero que a Virxe abrideira estaría entre elas, a xulgar por un pequeno detalle, ata o de agora inadvertido na documentación xerada polo preito entre a co-

27 Ese é o caso da cruz de cristal de roca, da que se falará despois, cuxas alteracións -nalgún momento indeterminado tras a Guerra Civil- poden documentarse comparando as publicacións de José Villa-amil y Castro (1899) e Marvin Chauncey Ross (1933) cos informes das últimas restauracións. As ditas alteracións inclúen a remontaxe da peza e, o que é peor, a substitución de parte das miniaturas medievais baixo cristal que a decoraban por outras imaxes de resaibo barroco. 
munidade clarisa e o bispo Eanes de Novoa. Nunha acta notarial escrita con motivo do dito preito, hoxe conservada grazas a un traslado feito contra 1647, faise alusión ao primeiro selo do convento, e ao da propia abadesa, Sancha Eanes, que aparecen descritos nos seus pormenores. Por este texto podemos saber que o selo de Santa Clara era «de forma longa e tinna en si imagen de Sancta Maria, seente en cadeira con seu fillo no braço e unha semellança de flor de lis en su mao, et as letras do seelo eran estas: Sigillum dominarum de Sancta Clara de conbentu de Allaris ${ }^{28}$. As coincidencias coa talla en marfil son evidentes, e non podo evitar pensar que este obxecto, sen dúbida o máis extraordinario de cantos gardasen as monxas e claro expoñente da condición rexia do convento, se convertería dende o primeiro momento nunha especie de imaxe corporativa para a comunidade. Se esta hipótese non é errada, o deseño do selo permitiría mesmo reconstruír o aspecto orixinal da obra, xa que a Virxe efectivamente parece soster un obxecto na súa man dereita, hoxe perdido, que ben podería ser unha flor de lis.

Se o exposto ata aquí non pasa de ser conxectural, a partir deste punto toda certeza desaparece. A infatigable Sancha Eanes reaparece noutro importante documento que, de novo, dá unha idea da precariedade da fundación rexia nestas primeiras décadas. Trátase doutro protocolo notarial, no que se procede á apertura e lectura pública do testamento de Violante en presenza do rei Fernando IV, o 22 de xaneiro de 1302, é dicir, tan só un día antes das nupcias do soberano con Constanza de Portugal $^{29}$. Para tal fin, a abadesa desprazaríase a Benavente, onde estaba a corte antes de partir para Valladolid, lugar onde se celebraría o enlace. Se Violante morrera, como parece máis probable, contra 1300 preto de Roncesvales, non pode dicirse dos seus descendentes inmediatos que se desen moita présa en cumprir coas súas derradeiras vontades $^{30}$. De facto, aínda que nesta altura se documentan algunhas mercés rexias e pode que a igrexa estivese xa rematada ao ano seguinte, cómpre pór en dúbida que as mandas testamentarias da raíña se fixesen efectivas, polo menos inmediatamente e de modo consistente ${ }^{31}$. Se, ademais, como aventura Mercedes Durany (2009: 141), Sancha Eanes finou pouco despois, é de supor que o convento ficaría nesa altura privado da súa máis enérxica defensora. Por este motivo, é necesario acoller con cautela as referencias ao padroado da raíña que achamos en fontes posteriores. Deixando á marxe as breves noticias que achega Ambrosio de Morales (1765: 158-159) -quen refire a existencia de «Reliquias menudas que dejó la Reyna en Cruces y Portapaces de pla-

28 A carta está datada o 2 de marzo de 1294. Foi publicada por López (1927: 34-35) e García Barriuso (1990: 34-35), e coméntaa García Oro (1988: 140). Consérvase en Madrid, AHN, Clero Secular-Regular, carp. 4900, n.․ㅡ 1 .

29 Aínda que a listaxe de testemuñas está incompleta, aparece encabezada por Juan Núñez de Lara e os seus partidarios. A raíña María de Molina, distanciada do seu fillo, non é mencionada no documento.

30 Así foi determinado por Enrique Flórez (1790: 369), a partir dunha breve noticia no Cronicón de Cardeña. As referencias a contrario por Gerónimo de Quiroga ou Jacobo de Castro carecen de fundamento, a pesar do que argumente Katz (2015: 826-830).

31 As concesións e mercés de Fernando IV detállanse en García Barriuso (1990: 41-45). 
ta», ademais de presentar unha lenda piadosa sobre a orixe da Virxe abrideira-, todos os investigadores que se ocuparon do tesouro allaricense parecen conceder fiabilidade a un inventario, datable en 1570, do que se conserva un traslado de 1647 entre a documentación que custodia o Archivo Histórico Nacional. Foi publicado parcialmente por Jacobo de Castro (1722: I, 327-328) na primeira parte do seu Arbol chronologico de la Santa Provincia de Santiago e tamén o transcribiron despois José Villaamil y Castro (1899: 133-134), Patrocinio García Barriuso (1990: 79-81) e outros autores ${ }^{32}$. En lugar de remitir a estas publicacións, coido que paga a pena presentalo aquí de novo para analizalo en detalle. Neste texto, no decurso dunha breve exposición sobre as persoas enterradas no convento, indícase que:

Tiene esta Sancta y Real casa muchas cosas que la Reyna Doña Violante traxo a ella. Tiene vna ymagen de Nuestra Señora de bulto de finissimo marfill que es vna de las mas devotas y preciossisimas que ay enel mundo; tiene vna puerta paz de plata mui bien guarneçida con su beril en medio delle está vn lignum crucis y en todo el demas hueco muchedumbre de diversas reliquias; y otra portapaz desta echura tambien de plata sobre dorada, que tiene de la faxa conque fue ceñido Christo nuestro redemptor y una estilla dela cuna y de la piedra del sepulcro de Nuestra Señora; Yten mas vn Sanctiago de plata de bulto con un escudo con su beril, y dentro otro pedaço del Lignum Crucis; Ytem mas vna cruz de plata hueca bien guarneçida que tiene vn dedo del bien aventurado San Bartholome; Yten mas otras dos cruçes de plata huecas como estan llenas de reliquias de diversos santos y santas quela reyna trajo a esta casa [...].

Yten estan aqui hornamentos que de su capilla dio a esta Sancta y Real casa frontales, capas, Casullas, palia, doseles.

Tiene mas que dio la reyna Doña Violante, otras ymagines de bulto de Nuestra Señora de marfil.

Yten mas tiene la cassa que dio la reyna Doña Violante tres cruçes de christal hermossisimas.

Como pode comprobarse, trátase dunha listaxe na que parecen incluírse obxectos de todo tipo e moi probablemente diferente cronoloxía, resultado de

32 Este inventario forma parte tamén do documento AHN, Clero Secular-Regular, carp. 4900, n.응 1. Segue a unha copia do testamento da raíña e ao protocolo notarial documentando a petición ao bispo de Silves, antes mencionado. Describe os seus contidos García Barriuso (1990: 103-106). Inclúo aquí a miña transcrición. 


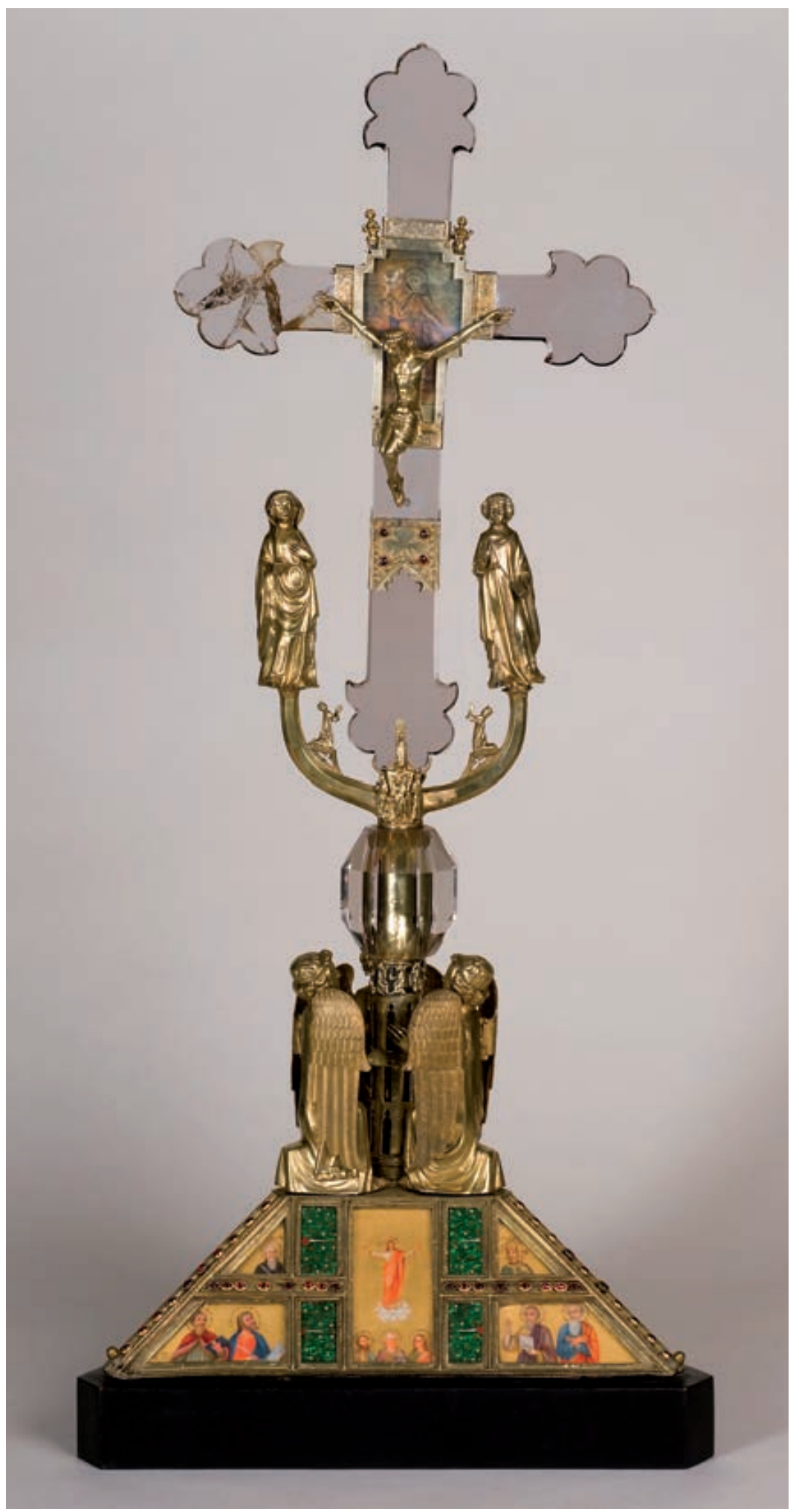

Fig. 7: Cruz de cristal de rocha do infante Felipe e Margarita de la Cerda (Real Monasterio de Santa Clara de Allariz). 
diversas doazóns ao longo do tempo. Ese sería o caso dunha imaxe de Santiago que, pola descrición, podería ser do século XIV ou mesmo posterior. A inmensa maioría deles non se conservan e é de imaxinar que desapareceron no lume de mediados do século XVIII (cf. González García 1990: 243-256). Tampouco parece que esta sección do documento, redactada por Francisco Hoyero [Siero?], vigairo do convento, mereza particular credibilidade, a xulgar pola alusión que se fai ao principio ao rei Jaume I, quen supostamente tería comezado a «edificar esta Sancta y Real casa en la hera de mill y tresçientos y veinte y quatro».

Con todo, tradicionalmente se quixo ver na cruz de cristal de roca conservada na institución (Fig. 7) unha das tres «hermossisimas» pezas incluídas neste inventario e, en consecuencia, parte da doazón fundacional de Violante, a pesar de que a análise estilística da obra leva a unha datación incompatible con esta posibilidade. Tanto a forma flordelisada da cruz, realizada en cristal veneciano, como as miniaturas baixo cristal, tamén de procedencia veneciana, non son anteriores á morte de Violante $^{33}$. Outro tanto pode dicirse dos esmaltes parisienses de plique ensamblados na base da cruz, e das imaxes de prata da Virxe, san Xoán, anxos e apóstolos que a decoran, de factura local e que remiten a obras aviñonensas datables na terceira década do século $\mathrm{XIV}^{34}$. Dado que dedicarei un estudo monográfico a esta peza extraordinaria, na que se probará que foi realizada para o infante Felipe (1292-1327) e a súa muller Margarita de la Cerda (1293-1328?), non me demorarei sobre esta cuestión aquí35. Outro tanto pode dicirse do fragmento ilustrado das Vidas y pasiones de los apóstoles de Bernardo de Brihuega, recentemente achado entre a documentación procedente de Allariz no AHPOu (Fragmentos, carp. 3, n. 4/5) ${ }^{36}$. Tan só quería alertar sobre os erros aos que nos pode conducir a falta de documentación fiable e o -comprensibledesexo de facer máis tanxible a lembranza dunha soberana poderosa que, abofé, tivo que verse rodeada de libros luxosos e ornamentos preciosos ${ }^{37}$.

Lamentablemente, debemos contentarnos cos testemuños albiscados e o balance agridoce que nos deixan. É de supor que a época de esplendor de Santa Clara de Allariz que conmemoraban os cronistas do século XVI fose máis ben a que resultou do padroádego do infante Felipe e Margarita de la Cerda, derradeiro

33 Así o argumentaron, respectivamente, Hahnloser/Brugger-Koch (1985: 124-125, n.o 135) e Spiandore (2014: 80-81 e 457-462).

34 Poden compararse cos recollidos en Gaborit-Chopin (1998: 206-217). Véxase tamén Taburet-Delhaye (1995: 13).

35 «La cruz de cristal de Allariz: Un manifiesto político transparente» (en preparación).

36 Dá noticia deste documento Ricardo Pichel en https://textorblog.wordpress.com/2019/04/08/ la-tradicion-vernacula-de-la-obra-de-bernardo-de-brihuega-noticia-de-un-nuevo-hallazgo/ [última consulta: abril 2021]. Véxase agora tamén un primeiro estudo destes fragmentos en Pichel (2021).

37 Por razóns de estilo tamén convén datar con posterioridade á morte da raíña (ca. 1330) o díptico-relicario de Santa Úrsula de Las Huelgas, que recentemente lle foi atribuído por Gómez-Chacón (2020). É moi probable que esta peza chegase ao mosteiro cisterciense tras a desamortización procedente dunha fundación dominica, San Pablo ou Caleruega. En calquera caso, non parece crible pensar, como fai Fuente Pérez (2017: 193), que o papel político desempeñado por Violante lle impedise dedicarse a actividades culturais. 
episodio dese preito sucesorio ao que tantas veces se aludiu neste traballo e ao que a fortuna do convento e novo panteón dinástico estaba indivisiblemente ligada. Para cando Afonso XI acabase con toda oposición interna, o tempo dunha gran fundación rexia xa pasara. A este respecto, resulta irónico e talvez premonitorio que a propia Violante non chegase a enterrarse en Allariz, como era o seu desexo. Mais iso non diminúe o interese e ambición dos seus designios para este territorio, que podería ter desempeñado un papel aínda máis importante no contexto peninsular se os plans da raíña se fixesen realidade. É certo que a visión afonsina acabaría por imporse nas centurias seguintes -na práctica, coa consolidación do eixe vertebrador norte-sur do reino e, de modo máis sutil, coa asimilación da súa concepción imperial pan-ibérica- pero coido que corresponde a Violante o xerme dese «ensayo de Infantazgo [masculino]» que García Oro (1988: 136) quixo ver no protagonismo dos infantes Juan e Felipe ao longo destas décadas. É precisamente a vella institución do Infantado a que vencella os exemplos analizados nestas páxinas, dende os tombos composteláns á fundación allaricense. Quizais sexa casualidade que Allariz se sitúe no triángulo imaxinario conformado por Xunqueira de Ambía, Porqueira e Celanova, terras que tradicionalmente pertenceran ás infantas de León ${ }^{38}$. O que non é coincidencia é que se poida recoñecer en Allariz a pegada de dous modelos rexios, o mosteiro cisterciense de Las Huelgas de Burgos e o priorado de Sigena, que, pola súa banda, trataran de adaptar a institución do Infantado aos novos tempos (Walker 2005). A descendencia de Allariz, pola súa vez, habería que procurala nos reinos veciños, en Santa Clara de Coimbra e Santa Clara de Pedralbes, onde dúas raíñas da Casa de Aragón continuarían o padrón da súa antecesora Violante. Serían estes os últimos elos dunha cadea de metamorfoses e estratexias a través das cales as mulleres das dinastías castelá-leonesa, aragonesa e portuguesa tratarían de crear refuxios onde retirarse e honrar a memoria dos seus, ou ben ámbitos de poder a través dos que continuar marcando os destinos dos seus reinos.

38 Estes territorios aparecen consignados no testamento da infanta Elvira (1099). Véxanse Martin (2008: §38) e Henriet (2008: §1-2). 


\section{REFERENCIAS BIBLIOGRÁFICAS}

- AvriL, François et alii (1983): Manuscrits enluminés de la Peninsule Ibérique, Paris, Bibliothèque Nationale de France.

- Benítez Guerrero, Carmen (2017): Crónica de Fernando IV. Estudio y edición de un texto post alfonsí, El Puerto de Santa María, Cátedra Alfonso X el Sabio/Universidad de Sevilla.

- BRANDÃo, Francisco (1980 [1672]): Monarquía Lusitana, Lisboa, Imprensa Nacional-Casa da Moeda.

- Cárdenas, Anthony (2009): «Alfonso X, Saint James, and the Virgin», Latin American Institute - Research Paper Series, 50, 3-37.

- Carrero Santamaría, Eduardo (2014): «Obispos y obras en Santiago de Compostela entre los siglos XII y XIII. La definición del espacio litúrgico en la catedral», en María Dolores Teijeira et alii (eds.), La creación artística en los reinos de Castilla y León (1050-1500), Madrid, Sílex, 173-201.

- CASTRO, Jacobo de (1722): Arbol Chronologico de la Provincia de Santiago, Salamanca, Francisco García Onorato y San Miguel.

- Cendón Fernández, Marta/Dolores Fraga SAmpedro (2017): «De la monarquía a la burguesía. Empresas artísticas en los conventos femeninos de la Galicia medieval», en Gemma-Teresa Colesanti et alii (eds.), Clarisas y dominicas. Modelos de implantación, filiación, promoción y devoción en la Península Ibérica, Cerdeña, Nápoles y Sicilia, Florencia, Firenze University Press, 339-383.

- Domenge, Joan/Anna Molina (2009): «Les “nobles i riquesofrenes” d'Isabel de Portugal. Orfebreries de la reina santa», en Princeses de terres llunyanas. Catalunya i Hongria a l'edatmitjana, Barcelona, Museu d'Historia de Catalunya/Magyar Nemzeti Múzeum, 307-323.

- Durany CASTRILLo, Mercedes (2009): «El monasterio de Santa Clara e Allariz», en Raquel Casal et alii (eds.), Galicia monástica. Estudios en homenaje a la profesora María José Portela Silva, Santiago de Compostela, Universidade, 131-152.

- Fernández Catón, José María (1990): El llamado Tumbo Colorado y otros códices de la Iglesia Compostelana: ensayo de reconstrucción, León, Centro de Estudios e Investigación «San Isidoro»/Archivo Histórico Diocesano.

- FERNÁNDEZ FERNÁNDEZ, Laura (2008): «Imagen e intención. La representación de Santiago Apóstol en los manuscritos de las Cantigas de Santa María», Anales de Historia del Arte, 18, 73-94.

- Ferreira, Pedro Manuel (2016): «The Medieval Fate of the Cantigas de Santa Maria», Journal of the American Musicological Society, 69:2, 295-353. 
- FlóREz, Enrique (1790): Memorial de las Reynas Catholicas. Historia genealógica de la casa real de Castilla y de León, Madrid, Viuda de Marín.

- Fournès, Ghislaine (2008): «Iconologie des infantes (Tumbo A et Tumbo B de la cathédrale de Saint-Jacques de Compostelle et Tumbo de Touxos Outos)», e-Spania, 5 (http://e-spania.revues.org/12033) [última consulta: abril 2021].

- Fuente Pérez, María Jesús (2017): Violante de Aragón. Reina de Castilla, Madrid, Dyckinson.

- Gaborit-Chopin, Danielle (coord.) (1998): L'art au temps des Rois Maudits: Philippe le Bel et ses fils, Paris, Reunion des Musées Nationaux.

- GaIBroIs, Mercedes (1922-1928): Historia del reinado Sancho IV de Castilla, Madrid, Tipografía de la «Revista de Archivos, Bibliotecas y Museos», 3 vols.

- Gaibrois, Mercedes (1936): María de Molina, tres veces reina, Madrid, Espasa-Calpe.

- Gallego, Olga (1986): «Dominio y bienes de Santa Clara», Boletín Auriense. Anexo: Santa Clara de Allariz, 70: Centenario da fundación, 43-61.

- García Barriuso, Patrocinio (1990): «Documentación sobre la fundación, privilegios y derechos históricos del monasterio de Santa Clara de Allariz», Liceo Franciscano, 127-129, 11-107.

- García Oro, José (1988): San Francisco de Asís en la España medieval, Santiago de Compostela, CSIC/Liceo Franciscano.

- García Oro, José (1990): «La primitiva instalación de las Clarisas en Galicia», Liceo Franciscano, 127-129, 109-145.

- Gómez-Chacón, Diana Lucía (2020): «Recuerdos de Hungría: la reina Violante de Aragón, Helena de Veszprém y el díptico-relicario de Santa Úrsula del monasterio de Las Huelgas de Burgos», De Arte, 19, 7-23.

- GonZÁLez García, Miguel Ángel (1990): «El arte en el monasterio de Santa Clara de Allariz», Liceo Franciscano, 127-129, 229-256.

- GonZÁlez JimÉneZ, Manuel (1991): Diplomatario andaluz de Alfonso X, Sevilla, Fundación El Monte.

- GonZÁlez JimÉnez, Manuel (ed.) (1998): Crónica de Alfonso X, Murcia, Real Academia de Alfonso X el Sabio.

- GonZÁlez JimÉneZ, Manuel (2004): Alfonso X el Sabio, Barcelona, Ariel.

- Graña CID, María del Mar (209): «The Mendicant Policies of the Queens of Castile in the Thirteenth Century. The Implantation of the Convents», en Nikolas Jaspert/ Imke Just (eds.), Queens, Princesses and Mendicants: Close Relations in a European Perspective, Zürich, LIT Verlag, 65-83.

- GutiérRez BAÑos, Fernando (2017): «La promoción artística en los conventos de Clarisas durante la Baja Edad Media: los coros de los conventos de Santa Clara de 
Salamanca y de Toro», en Mujeres en silencio: El monacato femenino en la España medieval, Aguilar de Campoo, Fundación Santa María la Real, 283-330.

- Hahnloser, Hans R./Susanne BrugGer-Koch (1985): Corpus der Hartsteinschliffe des 12.-15. Jahrhunderts, Berlin, Deutscher Verlag für Kunstwissenschaft.

- HenRiet, Patrick (2008): «Infantes, Infantaticum. Remarques introductives», e-Spania, 5 (http://e-spania.revues.org/12593) [última consulta abril 2021].

- Hoch, Adrian S. (1992): «Beata Stirps, Royal Patronage and the Identification of the Sainted Rulers in the St. Elizabeth Chapel at Assisi», Art History, XV:3, 279-295.

- JASPERT, Nikolas (1997): «Heresy and Holiness in a Mediterranean Dynasty: the House of Barcelona in the Thirteenth and Fourteenth Centuries», en D. I. Agius/ R. I. Netton (eds.), Across the Mediterranean Frontiers: trade, politcs and religion, 650-1450, Turnhout, Brepols, 105-135.

- JonEITIS, Diana (2008): «Ein früher Elisabethzyklus von Hof Alfons X. von Kastilien», Carl Justi Vereinigung, 20, 4-20.

- Joneitis, Diana/Dieter Blume (2007): «Eine Elisabeth-Handschrift vom König Alfons'X. von Kastilien», en Dieter Blume/Matthias Werner (eds.), Elisabeth von Thüringen, eine europäische Heilige. 3. Thüringer Landesausstellung. Aufsätze, Wartburg, Petersberg, 325-339.

- Katz, Melissa R. (2012): «The Non-gendered Appeal of Virge Ouvrant Sculpture: Audience, Patronage, and Purpose in Medieval Iberia», en Therese Martin (ed.), Reassessing the Roles of Women as «Makers> of Medieval Art and Architecture, Leiden, Brill, 37-91.

- Katz, Melissa R. (2013): «The Final Testament of Violante de Aragón (c. 1236-1300/01): Agency and (Dis)Empowerment of a Dowager Queen», en Elena Woodacre (ed.), Queenship in the Mediterranean: Negotiating the Role of the Queen in the Medieval and Early Modern Eras, London, Palgrave Macmillan, 51-71.

- Katz, Melissa R. (2015): «A Convent for La Sabia: Violante de Aragón and the Clarisas of Allariz» en James D'Emilio (ed.), Culture and Society in Medieval Galicia: A Cultural Crossroads at the Edge of Europe, Leiden, Brill, 812-836.

- Keller, John E. (1957): Collectánea Hispánica: Folklore and Brief Narrative Studies, Newark, Juan de la Cuesta, 61-68 («King Alfonso’s Virgin of Villa-Sirga: Rival of St. James of Compostela») e 69-76 («More on the Rivalry of St. James and Santa Maria»).

- KinKADE, Richard P. (1992-1993): «Violante of Aragon (1236/7-1300?): An Historical Overview», Exemplaria Hispanica, 2, 1-37.

- Klaniczay, Gabor (2002): Holy Rulers and Blessed Princesses. Dynastic Cults in Medieval Central Europe, Cambridge, Cambridge University Press. 
- Linehan, Peter (1971): The Spanish Church and the Papacy in the Thirteenth Century, Cambridge, Cambridge University Press.

- Linehan, Peter (1997): The Ladies of Zamora, University Park PA, Pennsylvania State University Press.

- LóPEZ, Atanasio (1927): «Apuntes históricos sobre el convento de Santa Clara de Allariz (siglos XIII y XIV)», Boletín de la Comisión Provincial de Monumentos Históricos y Artísticos de Orense, VIII:172, 8-18; 173, 25-32; 174, 49-53.

- Lucas Álvarez, Manuel (1998): La documentación del Tumbo A de la Catedral de Santiago de Compostela: estudio y edición, Santiago de Compostela, Cabildo de la S.A.M.I. Catedral de Santiago de Compostela/Seminario de Estudios Galegos.

- Martin, Georges (2008): «Le testament d'Elvire», e-Spania, 5 (http://e-spania. revues.org/12303) [última consulta: abril 2021].

- Mettmann, Walter (ed.) (1986): Alfonso X, Cantigas de Santa María, Madrid, Castalia, 3 vols.

- Morales, Ambrosio de (1765): Viage a los Reynos de León, y Galicia, y Principado de Asturias, Madrid, Antonio Marín.

- O'Callaghan, Joseph F. (1998): Alfonso X and the Cantigas: A Poetic Biography, Leiden, Brill.

- Pato DE MACEDo, Francisco (1999): «O túmulo gótico de Santa Clara, en José Ignacio Calvo Ruata (ed.), Imagen de la Reina Santa: Isabel, infanta de Aragón y Reina de Portugal, Zaragoza, Institución Fernando el Católico, 93-114.

- Pérez Rodríguez, Francisco Javier (2004): Os documentos do Tombo de Toxos Outos, Santiago de Compostela, Consello da Cultura Galega.

- PicheL, Ricardo (2019): «La tradición vernácula de la obra de Bernardo de Brihuega: noticia de un nuevo hallazgo», TextoR (https://textorblog.wordpress. com/2019/04/08/la-tradicion-vernacula-de-la-obra-de-bernardo-de-brihuega-noticia-de-un-nuevo-hallazgo/) [última consulta: abril 2021].

- Pichel, Ricardo (2021): «Las Vidas y pasiones de los apóstoles de Bernardo de Brihuega a la luz de un nuevo testimonio castellano», en Belén Almeida Cabrejas/ Fernando Larraz Elorriaga/Marina Serrano Marín (eds.), Babel a través del espejo. Libro homenaje a Joaquín Rubio Tovar, Alcalá de Henares, Universidad, 55-67.

- Prado Vilar, Francisco (2009): «Lacrimae rerum: San Isidoro de León y la memoria del Padre», Goya, 328, 195-221.

- Procter, Evelyn S. (1951): Alfonso X of Castile: Patron of Liteature and Learning, Oxford, Clarendon Press.

- Puente Míguez, José Miguel (1999): «La frustrada catedral gótica de Santiago de Compostela ¿eslabón perdido en las relaciones artísticas entre Francia y España 
en el siglo XIII?», en Christian Freigang (ed.), Gotische Architektur in Spanien, Frankfurt, Iberoamericana - Vervuert, 41-58.

- Ribeiro de Vasconcelos, Antonio G. (1894): Evolução do culto de Santa Isabel de Aragão, esposa do rei lavrador Dom Dinís de Portugal, a Rainha santa, Coimbra, s.e.

- RodrígueZ Moniño, Antonio (1950): «La colección de manuscritos del Marqués de Montealegre (1677)», Boletín de la Real Academia de la Historia, CXXVI, 427-492.

- Rodríguez Porto, Rosa M. (2011): Historia e culto das raíñas santas da Casa de Hungría nos reinos occidentais da Península (ss. XIII e XIV). Memoria inédita da Bolsa de Investigación da Deputación da Coruña.

- Rodríguez Porto, Rosa M. (2012): Thesaurum: La 'Crónica Troyana de Alfonso XI' (Escorial, h.I.6) y los libros iluminados de la monarquía castellana (1284-1369). Tese de doutoramento inédita. Santiago de Compostela, Universidade.

- Ross, Marvin Chauncey (1933): «O esmalte cloisonné da crús de Allariz», Nós, 112, 58-60.

- Rubio GarCía, Luis (1985): «En torno a la biblioteca de Alfonso X el Sabio», en Fernando Carmona/Francisco Javier Flores Arroyuelo (eds.), La lengua y la literatura en tiempos de Alfonso X. Actas del Congreso Internacional, Murcia, 5-10 marzo, 1984, Murcia, Universidad, 531-552.

- SÁnCHEZ AMEIJEIRAS, Rocío (2008): «Sobre las modalidades y funciones de las imágenes en el Tumbo A», en Tumbo A. Índice de los privilegios reales, que contiene este libro intitulado de la letra A: original conservado en la Biblioteca de la Catedral de Santiago, Santiago de Compostela, Archivo Biblioteca de la Catedral de Santiago/ Madrid, Editorial Testimonio, 143-216.

- SÁnchez AmeijeIRAS, Rocío (2009a): «Dando forma al tiempo: estrategias visuales y cartularios ilustrados», Studium Medievale, 2, 61-84.

- SÁnCHEZ AmeIJEIRAS, Rocío (2009b): «'Como a Virgen santa paresceu, paresçia’: Las empresas marianas alfonsíes y la teoría neoplatónica de la imagen sagrada”, en Isidro Bango Torviso (ed.), Alfonso X el Sabio, Murcia, Editora Regional de Murcia, 357-365.

- Sousa, António Caetano de (1793): Provas da Historia Genealogica da Casa Real Portugueza, Lisboa Occidental, Officina SYLVIANA da Academia Real.

- SPIANDORE, Silvia (2014): Preziose trasparenze: La miniatura veneziana sotto cristallo di rocca (secoli XIII-XIV). Tese de doutoramento inédita. Padua, Università di Padova.

- TABURET-DeLHAYE, Elisabeth (1995): «L'orfèvrerie au poinçon d'Avignon au XIV siècle», Revue de l'art, 108, 11-22.

- TORRes Fontes, Juan (1976): «La Orden de Santa María de España», Miscelánea Medieval Murciana, 3, 73-118. 
- VAUCHEZ, André (1977): Beata stirps: sainteté et lignage en Occident au XIII et XIV siècles», en Georges Duby/Jacques le Goff (eds.), Famille et parenté dans l'Occident medieval, Rome, École Française de Rome, 397-407.

- Villa-amil y CASTRo, José (1899): «Cruz de cristal conservada en Allariz», Boletín de la Comisión Provincial de Monumentos Históricos y Artísticos de Orense, I:8, 129-136.

- WALKER, Rose (2005): «Leonor of England, Plantagenet Queen of King Alfonso VIII of Castile, and her foundation of the Cistercian abbey of Las Huelgas. In imitation of Fontevraud?», Journal of Medieval History, 31, 346-368.

- WEBSTER, James (1993): Els Menorets: the Franciscans in the realms of Aragón from St. Francis to the Black Death, Toronto, Pontifical Institute. 